\title{
Design an Android-based Chemical Bond Application
}

\author{
Muhammad Zulfadhilah \\ Sari Mulia University \\ Department of Information \\ Technology
}

\author{
Nur Hidayah \\ Sari Mulia University \\ Department of Information System
}

\author{
Muhammad Syahid Pebriadi \\ Banjarmasin State Polytechnic \\ Department of Computer \\ Accounting
}

\begin{abstract}
Chemical bonds are one of the basic materials and are important in understanding the mechanisms and chemical reactions and other materials such as stoichiometry and so on. Chemistry bonding material is studied and understood starting from junior high school up to undergraduate students for the science majors at tertiary institutions. The many types of chemical bonds that may occur in the joining of two or more elements make the most of the learning for this material more difficult. In this paper the research designs and builds an application by applying the basics of chemical bonds as learning innovations to facilitate the understanding of studying chemistry. This application is designed using the SDLC (System Development Lite Cycle) system development model or system development life cycle. The SDLC model to be used is the systematic, sequential waterfall method in building software from this research. For the programming language used is Java and uses the MySql Database.
\end{abstract}

\section{Keywords}

Android application, Chemical Association, Java, Mysql

\section{INTRODUCTION}

The rapid development of information technology is indirectly a demand and effort in improving the quality of education in general and improving learning systems today [1]. Technology can improve quality and reach if used wisely in the field of education and training, because technology and education have a very important meaning for the economic welfare of the community in general. Opinions from Alisjahbana suggest that the Education and training approach will be "just on time" and new learning techniques will be two-way, collaborative and interdisciplinary [2].

The researchers think that mobile devices will provide many opportunities, this is due to an increase and expansion of technological opportunities, many technological developments are integrated with the field of education [3]. The use of mobile devices which is very much now opens the opportunity to use mobile devices in the education process. The use of mobile devices in the learning process is known as cellular learning [4]. The proposed mobile application is designed to reduce manuals work and ease teaching and learning in the academic field [5].

Based on this background, the writer will explain the results of making an android-based application that focuses on basic chemistry, this application is expected to be used as a medium for the learning process.

\section{RESEARCH METHODS}

The research method used in this study uses the system development model SDLC (System Development Lite Cyle), the SDLC model that will be used is the waterfall method. This model is shown in Figure 1 below :

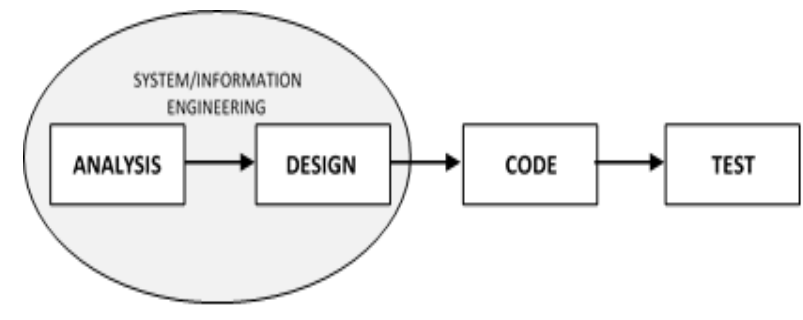

Fig 1 : Waterfall Method [4]

1. Analysis

The analysis phase is the stage used to find out the needs of building a system. At this stage data analysis will be carried out which will be taken for system requirements.

\section{Design}

System design consists of database design and interface design. This stage also aims to provide an overview of the system workflow. Database design will be done later with conceptual, logical and physical. Interface design is done to design a user-friendly display while for later process design using activity diagrams.

\section{Code}

Code is the implementation in the form of a program or coding to make the Design and Application Development of Android-Based Chemical Bonding. The programming language used is Java and uses the MySql Database.

\section{Test}

Tests carried out to avoid errors from the system made. If an error occurs, the system will be repaired again until the process results are in accordance with what is expected. The test was conducted on several high school students. At this stage researchers who are involved in the field of Chemistry will participate in testing, so that the output of the results of this application in accordance with what is expected by both researchers and in accordance with the needs of respondents later.

\section{LITERATURE REVIEW}

\subsection{Basic Concepts of Application}

Mobile applications are software that runs on mobile devices such as smartphones or tablet PCs. Mobile applications are also known as applications that can be downloaded and have certain functions that increase the functionality of the mobile device itself. To get the desired mobile application, users can download it through certain sites in accordance with the operating system they have. Google Play and iTunes are some examples of sites that provide various applications for Android and iOS users to download the desired application [6]. Mobile applications can easily do a variety of activities ranging from entertainment, selling, studying, doing office work, browsing and so forth. Utilization of mobile applications for entertainment is the most popular by almost 
$70 \%$ of cell phone users, because by utilizing the features of games, music players, until the video player makes it easier for us to enjoy entertainment anytime and anywhere [7].

\subsection{Android}

Android allows developers to create software using a consolidated programming language to control devices through a library developed by Google. Android is an open source and comprehensive platform specifically designed for use in mobile electronic devices. The Android platform has revolutionized mobile devices from the start because it is very open and is able to separate hardware from software that runs on it efficiently [8].

\subsection{Chemical Bond}

Chemical bonding is a physical process that is responsible for the interaction of attractive forces between two atoms or molecules that causes a diatomic or polyatomic compound to become stable. There are several types of chemical bonds that may occur in the joining of two or more elements, namely:
a. Ion Bonding
b. Covalent bonds
c. Covalent bond of coordination
d. Metal bonding
e. Hydrogen bonding
f. Ligands complex

Each bond has its own characteristics that distinguish between bonds. These differences generally cause differences in the physical and chemical properties of compounds formed from these bonds [9].

\section{RESULT}

The process of making this application involves the role of prospective users among high school students. The students involved were distributed questionnaires in stages, the first stage was the stage of filling out the questionnaire before making the application and the second stage was the stage of filling out the questionnaire after the application trial. The first stage questionnaire was conducted to find out how much the use of the application as one of the media to increase student knowledge in the learning process, while the second stage was carried out how much the impact of the application in the learning process.

Prospective user data among students is taken from several different schools, the sample taken is 30 prospective users among high school students. The results obtained state that there are $87 \%$ of students still using print media as literature and the remaining $13 \%$ are already using non-print media as learning media. Based on the data obtained there are $37 \%$ already using the Internet media in the process of learning basic chemistry, while $63 \%$ of students still use conventional media in the learning process. In addition, the data obtained also shows that $33 \%$ of students have used an Android-based application in the learning process and $67 \%$ have not used an Android application. Figure 2 below shows the results of filling out the questionnaire before making the application.

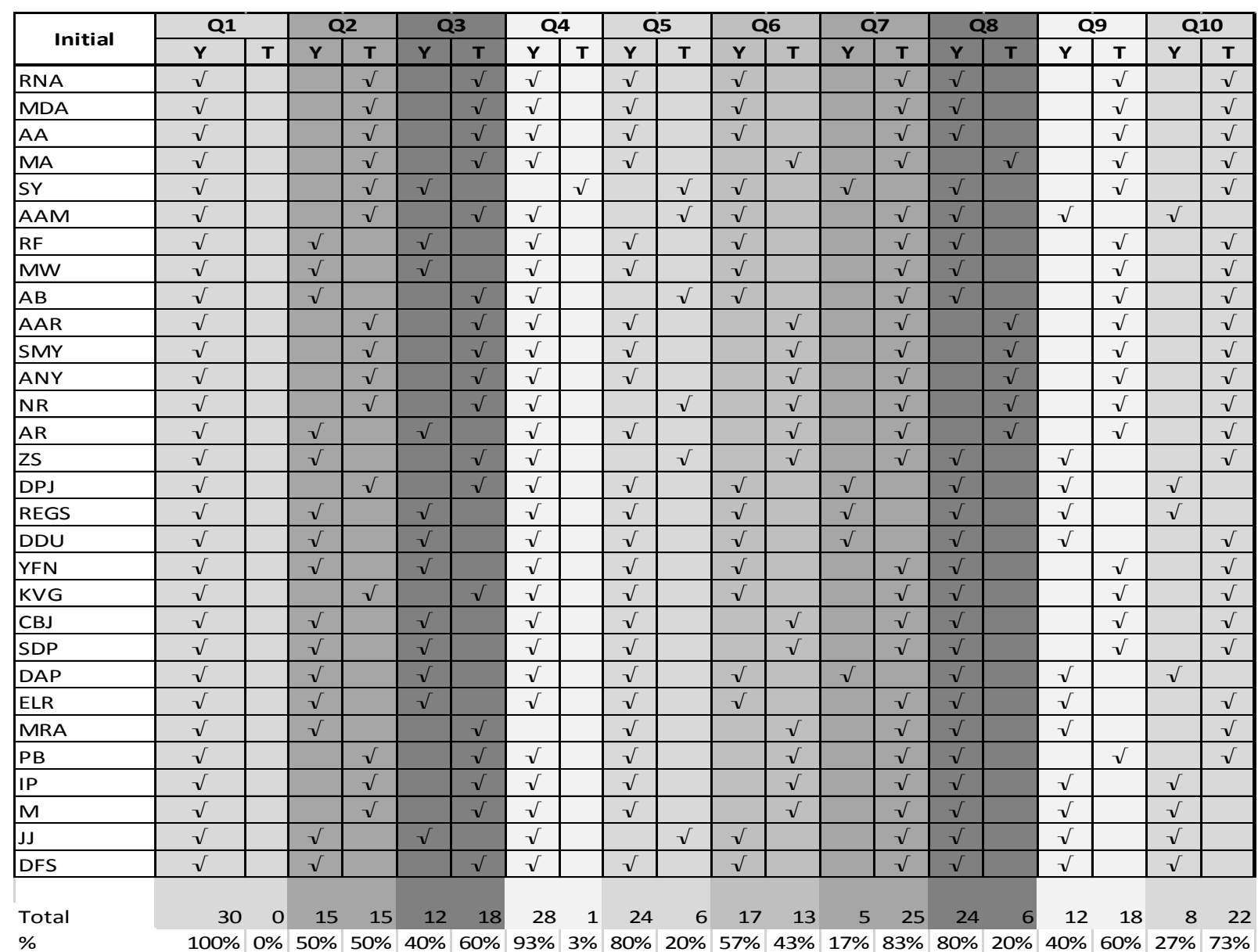

Fig 2 : Questionnaire data before making the application 
Based on the data above, an Android-based application was made as a medium of learning in basic chemistry. In this application offers several features, namely periodic tables and chemical calculators. In the periodic table feature, it displays chemical elements in detail and can link to information sites like Wikipedia and YouTube. The next feature is a chemical calculator, this feature is a mainstay feature made on this Android application, this feature serves to see the possibility of chemical bonds between the two elements calculated.

In Figure 3 below is the initial appearance of the application that has been made and tested by prospective users, in this case high school students.

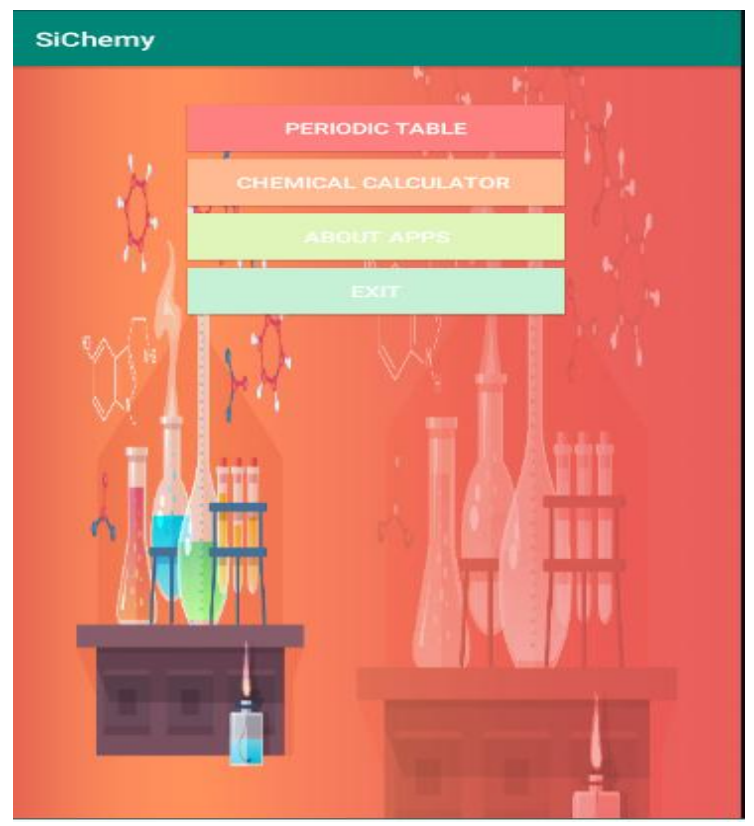

Fig 3 : Initial display applications

On the main menu, there are several options, namely the periodic table, the chemical calculator, about the application and exit the application. In the periodic table selection, if selected then will display a periodic table of chemical elements, such as Figure 4 below.

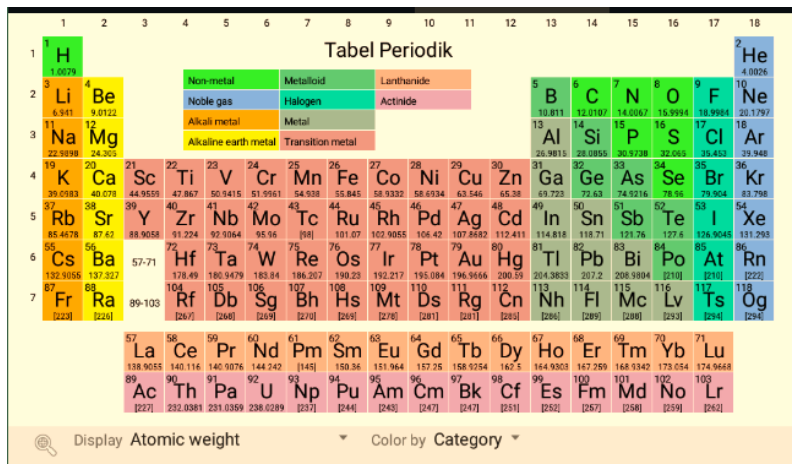

Fig 4 : Table Periodic

In this feature, the periodic table display can be adjusted to the needs of the user, on the interface there is a display menu for the periodic table, whether by category or color, or if you want to display elements of atoms or melting points or other, it can be adjusted to the user's needs during use. In this feature, detailed elements can be seen by tapping one of the elements, then the element details will appear like Figure 5 below.

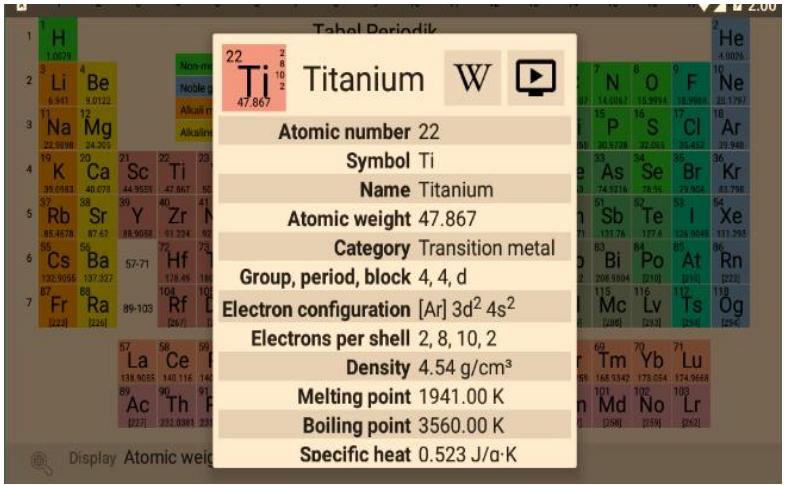

Figure 5 Element Detail

In the detailed information, you can see the Wikipedia logo and video that will lead to YouTube videos. This is to make it easier for users if they want to find out more about the elements they have chosen.

\begin{tabular}{|l|}
\hline Sichemy \\
\hline 0 \\
\hline CALCULATE \\
P205 \\
POCI3 \\
H4P206
\end{tabular}

Fig 6 : Chemical Calculator

Chemical calculator feature which is the mainstay of this application has a way of working combines two elements to look at the possibility of chemical bonds formed from elements earlier. An example can be seen in Figure 5 above.

In Figure 6 is shown the results of calculations / second matching element to search the leash, the results indicate the possibility of a bond formed by the two elements that have been incorporated. The existing results can be seen detailed information by tapping one of the lists of results displayed, it will look like Figure 7 below.

\section{Sichemy}

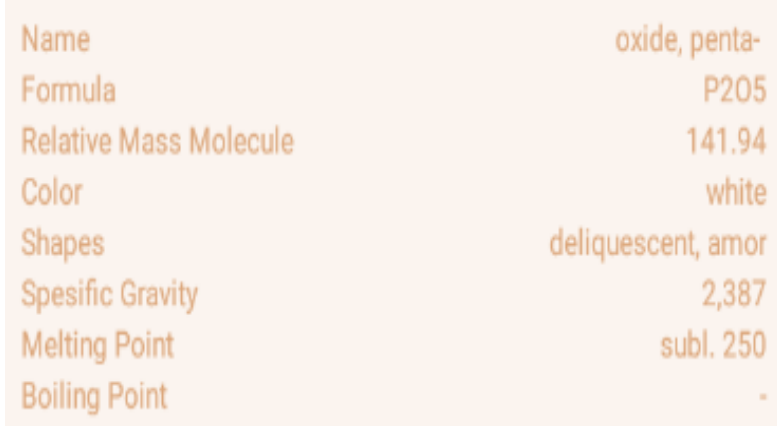

Fig 7 : Detailed Chemical Bond Information 
Applications that have been made tested on prospective users, in this case are high school students in several schools. Application trials were followed by distributing questionnaires to students, and the results of distributing questionnaires to students expressed satisfaction with the application and were very helpful in the learning process. Applications can also be used as one of the learning media on basic chemistry at the high school level.

\begin{tabular}{|c|c|c|c|c|c|c|c|c|c|c|c|c|c|c|}
\hline \multirow{2}{*}{ Initial } & \multicolumn{2}{|c|}{ Q1 } & \multicolumn{2}{|c|}{$Q 2$} & \multicolumn{2}{|c|}{ Q3 } & \multicolumn{2}{|c|}{$\mathbf{Q 4}$} & \multicolumn{2}{|c|}{ Q5 } & \multicolumn{2}{|c|}{ Q6 } & \multicolumn{2}{|c|}{ Q7 } \\
\hline & $\mathbf{Y}$ & $\mathbf{T}$ & $Y$ & $\mathbf{T}$ & $Y$ & $\mathbf{T}$ & $Y$ & $\mathbf{T}$ & $\mathbf{Y}$ & $\mathbf{T}$ & $\mathbf{Y}$ & $\mathbf{T}$ & $Y$ & $\mathbf{T}$ \\
\hline RNA & $\sqrt{v}$ & & $\sqrt{ }$ & & $\sqrt{ }$ & & $\sqrt{ }$ & & $\sqrt{ }$ & & $\sqrt{ }$ & & $\sqrt{ }$ & \\
\hline MDA & $\sqrt{ }$ & & $\checkmark$ & & $\sqrt{ }$ & & 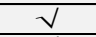 & & $\checkmark$ & & 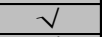 & & $\checkmark$ & \\
\hline $\mathrm{AA}$ & $\checkmark$ & & $\checkmark$ & & $\sqrt{ }$ & & 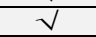 & & $\checkmark$ & & v & & $\sqrt{ }$ & \\
\hline MA & $\sqrt{ }$ & & $\sqrt{v}$ & & $\sqrt{ }$ & & $\sqrt{v}$ & & $\sqrt{ }$ & & $\sqrt{v}$ & & $\sqrt{ }$ & \\
\hline SY & $\checkmark$ & & $\checkmark$ & & $\sqrt{v}$ & & $\checkmark$ & & $\checkmark$ & & 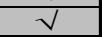 & & 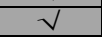 & \\
\hline AAM & $\sqrt{ }$ & & $\sqrt{ }$ & & $\sqrt{ }$ & & $\sqrt{v}$ & & $\sqrt{ }$ & & $\sqrt{v}$ & & $\sqrt{v}$ & \\
\hline RF & $\checkmark$ & & v & & $\sqrt{v}$ & & v & & $\checkmark$ & & 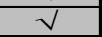 & & $\sqrt{ }$ & \\
\hline MW & $\sqrt{ }$ & & $\checkmark$ & & $\sqrt{ }$ & & $\sqrt{v}$ & & $\sqrt{ }$ & & $\sqrt{v}$ & & $\sqrt{v}$ & \\
\hline AB & $\checkmark$ & & $\checkmark$ & & $\sqrt{ }$ & & 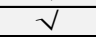 & & $\checkmark$ & & 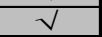 & & $\sqrt{v}$ & \\
\hline AAR & $\sqrt{ }$ & & $\sqrt{ }$ & & $\sqrt{ }$ & & v & & $\sqrt{ }$ & & $\sqrt{v}$ & & $\sqrt{ }$ & \\
\hline SMY & $\checkmark$ & & $\checkmark$ & & $\sqrt{ }$ & & $\sqrt{v}$ & & $\sqrt{ }$ & & $\sqrt{ }$ & & $\sqrt{ }$ & \\
\hline ANY & $\sqrt{ }$ & & $\checkmark$ & & $\checkmark$ & & v & & $\checkmark$ & & $\sqrt{ }$ & & $\sqrt{ }$ & \\
\hline NR & $\sqrt{ }$ & & $\sqrt{ }$ & & $\sqrt{v}$ & & $\sqrt{v}$ & & $\sqrt{ }$ & & $\sqrt{v}$ & & $\sqrt{v}$ & \\
\hline AR & $\sqrt{ }$ & & $\checkmark$ & & $\sqrt{ }$ & & $\sqrt{ }$ & & $\sqrt{ }$ & & $\sqrt{ }$ & & $\sqrt{ }$ & \\
\hline $\mathrm{ZS}$ & $\sqrt{ }$ & & $\checkmark$ & & $\sqrt{ }$ & & $\sqrt{v}$ & & $\checkmark$ & & $\sqrt{ }$ & & $\sqrt{v}$ & \\
\hline DPJ & $\sqrt{ }$ & & $\checkmark$ & & $\sqrt{ }$ & & $\sqrt{ }$ & & $\checkmark$ & & v & & $\checkmark$ & \\
\hline REGS & $\sqrt{ }$ & & $\checkmark$ & & $\sqrt{ }$ & & $\sqrt{v}$ & & $\sqrt{ }$ & & $\sqrt{ }$ & & $\sqrt{v}$ & \\
\hline DDU & $\sqrt{ }$ & & $\sqrt{ }$ & & $\sqrt{ }$ & & $\sqrt{v}$ & & $\checkmark$ & & $\sqrt{ }$ & & $\sqrt{ }$ & \\
\hline YFN & $\sqrt{ }$ & & $\checkmark$ & & $\checkmark$ & & $\sqrt{v}$ & & $\checkmark$ & & $\sqrt{v}$ & & $\sqrt{v}$ & \\
\hline KVG & $\sqrt{ }$ & & 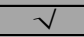 & & $\sqrt{ }$ & & $\sqrt{v}$ & & $\checkmark$ & & $\sqrt{ }$ & & $\sqrt{ }$ & \\
\hline CBJ & $\sqrt{ }$ & & $\sqrt{ }$ & & $\sqrt{ }$ & & $\sqrt{v}$ & & $\sqrt{ }$ & & 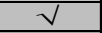 & & $\sqrt{ }$ & \\
\hline SDP & $\sqrt{ }$ & & $\sqrt{ }$ & & $\checkmark$ & & $\sqrt{ }$ & & $\sqrt{ }$ & & $\sqrt{v}$ & & 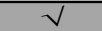 & \\
\hline DAP & $\sqrt{ }$ & & $\sqrt{ }$ & & $\sqrt{ }$ & & $\sqrt{ }$ & & $\sqrt{ }$ & & $\sqrt{ }$ & & $\sqrt{ }$ & \\
\hline ELRR & $\sqrt{ }$ & & $\sqrt{ }$ & & $\sqrt{ }$ & & $\sqrt{ }$ & & $\sqrt{ }$ & & $\sqrt{v}$ & & $\sqrt{v}$ & \\
\hline MRA & $\sqrt{ }$ & & $\checkmark$ & & $\sqrt{ }$ & & $\sqrt{v}$ & & $\sqrt{ }$ & & $\sqrt{ }$ & & $\sqrt{ }$ & \\
\hline PB & $\sqrt{ }$ & & $\sqrt{ }$ & & $\sqrt{ }$ & & $\sqrt{v}$ & & $\sqrt{ }$ & & $\sqrt{v}$ & & $\sqrt{v}$ & \\
\hline IP & $\sqrt{ }$ & & $\checkmark$ & & $\sqrt{ }$ & & $\sqrt{ }$ & & $\checkmark$ & & $\sqrt{ }$ & & $\checkmark$ & \\
\hline$M$ & $\sqrt{ }$ & & $\sqrt{ }$ & & $\sqrt{ }$ & & $\sqrt{v}$ & & $\sqrt{ }$ & & $\sqrt{v}$ & & $\sqrt{v}$ & \\
\hline JJ & $\sqrt{ }$ & & $V$ & & $\sqrt{ }$ & & $\sqrt{v}$ & & $\checkmark$ & & $\sqrt{ }$ & & $\checkmark$ & \\
\hline DFS & $\sqrt{ }$ & & $\checkmark$ & & $\checkmark$ & & $\checkmark$ & & $\checkmark$ & & 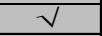 & & $\checkmark$ & \\
\hline SN & $\sqrt{ }$ & & $\checkmark$ & & $\checkmark$ & & $\checkmark$ & & $\checkmark$ & & 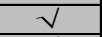 & & $\checkmark$ & \\
\hline MRZM & $\sqrt{ }$ & & $\checkmark$ & & $\checkmark$ & & $\checkmark$ & & $\checkmark$ & & $\sqrt{ }$ & & $\checkmark$ & \\
\hline MR & $\sqrt{ }$ & & $\checkmark$ & & $\sqrt{ }$ & & $\sqrt{ }$ & & $\sqrt{ }$ & & $\sqrt{ }$ & & $\sqrt{ }$ & \\
\hline EGR & $\sqrt{ }$ & & $\checkmark$ & & $\checkmark$ & & $\checkmark$ & & $\checkmark$ & & $\sqrt{ }$ & & $\checkmark$ & \\
\hline & & O & 34 & O & 34 & O & 34 & o & 34 & $\mathbf{O}$ & 34 & o & 34 & O \\
\hline & 100 & $0 \%$ & $100 \%$ & $0 \%$ & $100 \%$ & $0 \%$ & $100 \%$ & $0 \%$ & $100 \%$ & $0 \%$ & $100 \%$ & $0 \%$ & $100 \%$ & $0 \%$ \\
\hline
\end{tabular}

Figure 8 Questionnaire After Application Testing

The picture above is the result of distributing the questionnaire when testing the application. In the questionnaire all users (in this case high school students) feel very satisfied with the application that has been made, both from the interface, features on the application and information obtained as material for learning chemistry in schools.

Making this application aims to help users, in this case students in understanding basic chemistry learning material. This learning media is one of the interactive learning media, which according to [10] interactive learning application is a program that packs a computer-assisted learning method that can provide a response back to the end user (students) of what has been inputted to the application. This is also in line with research [11] which states that the presence of mobile learning using smart phone electronic media is intended as a supplement to existing learning and provides opportunities for students to learn themselves about material that is not well mastered in anytime and anywhere.

The use of the application as a learning medium has been carried out by several researchers, in research conducted by the Mobile Edugame Design [12] aims to be one of the learning innovations in the introduction of atomic bonds in chemistry for high school students, as well as Android Application Development as a medium for learning mathematics in the three dimensional material for high school students in class $X$ [13] which aims to assist students in understanding mathematics in school by using the application.
During the trial, students were very interested in using the application, the results of this study are consistent with research conducted by [14] which states that the majority of elementary school students in Taiwan have a cellphone, it would be more fun for students if they could use their cellphones to study this problem.

\section{CONCLUSION}

The process of making an application, carried out filling out the questionnaire to students before and after the trial application. The results of the questionnaire before using the application stated $63 \%$ of users have not used the application as a learning medium. after conducting a trial of this application, the results of the questionnaire stated the conclusion that the application was very helpful and interactive in its use.

In further research, it is expected that the features of the application can be complemented by a bonding image and the appearance of the application can be improved to make it more convenient to use.

\section{ACKNOWLEDGMENTS}

Thank you to the "Ministry of Research, Technology and Higher Education" for funding this research so that it can be carried out to completion. Thank you also to YouTube Channel Periodic Videos for providing information related to chemical elements in the periodic table. 


\section{REFERENCES}

[1] T. Andiani, "Sistem Pembelajaran Berbasis Teknologi Informasi dan Komunikasi," Sos. Budaya Media Komun. Ilmu-Ilmu Sos. dan Budaya, vol. 12, no. 1, 2015.

[2] T. Sutabri, Pengantar Teknologi Informasi, 1st ed. Yogyakarta: CV. Andi Offset, 2014.

[3] P. Kirci and M. O. Kahraman, "Game based education with android mobile devices," in 6th International Conference on Modeling, Simulation, and Applied Optimization, ICMSAO 2015 - Dedicated to the Memory of Late Ibrahim El-Sadek, 2015, pp. 4-7.

[4] R. Isnaini, Basori, R. A. Yuana, and D. Maryono, "Designing Android reward system application in education to improve learning quality," Proc. - 2017 4th Int. Conf. Inf. Technol. Comput. Electr. Eng. ICITACEE 2017, vol. 2018-Janua, pp. 9-14, 2018.

[5] U. Singh, N. Srivastava, and A. Kumar, "JIIT-edu: An android application for college faculty," 2016 9th Int. Conf. Contemp. Comput. IC3 2016, pp. 1-6, 2017.

[6] M. Irsan, "Rancang Bangun Aplikasi Mobile Notifikasi Berbasis Android untuk Mendukung Kinerja di Instansi Pemerintahan," vol. 1, no. 1, 2015.

[7] R. Farizah, Nur and Kosidin, "Pemodelan aplikasi mobile reminder berbasis android," Semin. Nas. Teknol. Inf. dan Komunikas, vol. 2016, no. Sentika, pp. 18-19, 2016

[8] G. P. Landi, F. A. S. Gonçalves, F. P. Marafão, and H. K.
M. Paredes, "Interactive android application for education in AC-to-DC converters," in 14th Brazilian Power Electronics Conference, COBEP 2017, 2018, vol. 2018-Janua, pp. 1-5.

[9] J. E. Brady, Kimia Universitas: Asas dan Struktur. Jakarta: Binarupa Aksara, 2000.

[10] I. Rizkiansyah, "Pengembangan Aplikasi Pembelajaran Ineraktif Teknik Bermain Piano Berbasis Multimedia di Lembaga Kursus Musik 'Ethnictro' Yogyakarta," J. Inform., 2015.

[11] M. Iqbal, Y. Yusrizal, and M. Subianto, "Perancangan Media Pembelajaran Aplikasi Fisikapada Pokok Bahasan Fluida Statis Untuk Siswa Sma Berbasis Android," J. Pendidik. Sains Indones., vol. 4, no. 2, pp. 20-24, 2016.

[12] I. B. K. Widiartha and H. Wijayanto, "Rancang Bangun Mobile Edugame Ikatan Atom Pada Matapelajaran Kimia Untuk Siswa Sekolah Menengah Atas," vol. 9, no. 1,2010 .

[13] R. julia Purbasari, M. S. Kahfi, and M. Yunus, "Pengembangan Aplikasi Android Sebagai Media Pembelajaran Matematika Pada Materi Dimensi Tiga Untuk Siswa SMA Kelas X," J. Online Univ. Negeri Malang, pp. 1-11, 2013.

[14] W. K. Wong, C. H. Lin, and K. P. Chen, "Spoonbill game on android devices for ecological education," in Proceedings - IEEE 18th International Conference on Advanced Learning Technologies, ICALT 2018, 2018 pp. 143-145. 